\author{
Vol. 14 No. 1 April 2020 \\ (ISSN Cetak 1978-6573) (ISSN Online 2477-300X)
}

\title{
PENGARUH KINERJA TENAGA MEDIS DAN PELAYANAN KESEHATAN TERHADAP SISTEM REPUTASI LAYANAN PUBLIK PADA PUSKESMAS METRO
}

\author{
Andhina Martatilova \\ Universitas Muhammadiyah Metro \\ andhinamartatiluva@gmail.com
}

\begin{abstract}
ABSTRAK
Penelitian ini dilakukan di Pusat Kesehatan (Puskesmas) Kota Metro pada tanggal 28 November 2019. Jenis penelitian ini menggunakan pendekatan kuantitatif dan teknik pengumpulan data menggunakan pengamatan dan kuesioner. Populasi dalam studi ini berjumlah 90 orang dan dianalisis menggunakan regresi linier berganda dengan SPSS versi 21. Berdasarkan hasil analisis dapat disimpulkan bahwa kinerja tenaga medis berpengaruh pada sistem reputasi pelayanan publik di Puskesmas Metro. Hal tersebut dikarenakan kinerja personil medis telah baik sehingga dapat meningkatkan sistem reputasi layanan publik. Selain itu, layanan kesehatan berpengaruh pada sistem reputasi di Puskesmas Metro. Hal tersebut dikarenakan layanan kesehatan telah dilaksanakan dengan baik sehingga dapat meningkatkan sistem reputasi pelayanan publik. Selanjutnya, kinerja tenaga medis dan pelayanan kesehatan secara simultan berpengaruh pada sistem reputasi pelayanan publik di Puskesmas Metro. Hal ini dikarenakan adanya kombinasi yang maksimal antara kinerja tenaga medis dan pelayanan kesehatan agar dapat meningkatkan sistem reputasi pelayanan publik.
\end{abstract}

Kata kunci: Kinerja Tenaga Medis, Pelayanan Kesehatan, Sistem Reputasi Pelayanan Publik

\begin{abstract}
This research was conducted at the Metro Health Center on November 28, 2019. This type of research uses a quantitative approach and data collection techniques using observations and questionnaires. The population in this study amounted to 90 people and analyzed using multiple linear regression with SPSS version 21. Based on the analysis it can be concluded that there is an effect of the performance of medical personnel on the public service reputation system at the Puskesmas Metro. This is because the performance of medical personnel has been good so that it can improve the public service reputation system. In addition, there is an influence of health services on the reputation system for public services in Metro Puskesmas. This is because health services have carried out well so as to improve the reputation system of public services. Then, there is an effect of the performance of medical personnel and health services simultaneously on the reputation system for public services in the Metro Puskesmas. This is because there is a maximum combination of performance of medical personnel and health services so as to be able to improve the reputation system of public services.
\end{abstract}

Keywords: Medical Personnel Performance, Health Services, Public Service Reputation Systems

\section{PENDAHULUAN}

Kemajuan teknologi informasi yang kian memuncak memberikan alihalih dampak positif dan dampak negatif kepada berbagai pihak terutama dalam bidang pelayanan. Jika kemajuan tersebut digunakan untuk hal yang positif tentunya akan memberikan nilai manfaat yang besar. Namun sebaliknya apabila salah dalam dipergunakannya akan memberikan dampak negatif. 
Terbentuknya suatu sistem pada suatu pelayanan publik tentunya disertai beberapa problematika yang terdapat di dalamnya. Dari beberapa permasalahan yang terdapat pada penelitian sebelumnya menemukan bahwa fasilitas pengaduan kesehatan belum optimal, dikarenakan masih menggunakan sistem kotak saran sehingga keluh kesah yang dirasakan masyarakat tidak dapat tersampaikan untuk membangun kinerja tenaga medis dan pelayanan kesehatan yang terdapat pada puskesmas (Irmawati, Lukman, \& Nurhannis, 2017: 190).

\begin{tabular}{llr}
\multicolumn{1}{c}{ Dalam } & \multicolumn{1}{c}{ halnya mendapatkan } \\
pelayanan & kesehatan & tentunya \\
masyarakat & sebagai & pengonsumsi \\
pelayanan tersebut ingin mendapatkan & mendin \\
pelayanan secara maksimal. Bagi \\
masyarakat yang mengalami sakit,
\end{tabular} penanganan yang lama itu sangat fatal di tambah lagi dengan tenaga medis yang tidak sedang berada pada jam kerja (Saputra \& Harahap, 2016: 5).

Berdasarkan observasi yang dilakukan peneliti selama 3 hari pada tanggal 17-19 September 2019 menunjukkan ada beberapa keluhan masyarakat terkait dengan pelayanan pengantrian dan pendataan masyarakat yang dilakukan secara tidak cepat sehingga waktu mengantri kian lama dan masyarakat menilai kinerja petugas puskesmas tidak profesional. Hal itu disebabkan ditemukannya petugas yang asik mengobrol saat sedang bekerja melayani masyarakat.

Menurut Undang-Undang No. 25 Tahun 2009 tentang pelayanan publik menunjukkan bahwa pelayanan publik adalah segala bentuk kegiatan dalam rangka pengaturan, pembinaan, bimbingan, penyediaan fasilitas, jasa dan lainnya yang dilaksanakan oleh aparatur pemerintah sebagai upaya pemenuhan kebutuhan kepada masyarakat sesuai dengan ketentuan perundang-undangan yang berlaku. Sebenarnya tujuan pemerintah Metro sendiri dalam menerapkan sistem reputasi layanan publik untuk menciptakan integrasi dan kekuatan pembangunan melalui partisipasi aktif masyarakat dan kerja profesional pemerintah (Dinas Komunikasi dan Informatika, 2017).

Berdasarkan Peraturan Menteri Kesehatan Republik Indonesia No. 24 Tahun 2015 tentang penilaian fasilitas kesehatan tingkat pertama berprestasi dalam ruang lingkup penilaian puskesmas yaitu sebagai berikut.

\section{A. Kategori Puskesmas berdasarkan} karakteristik Kawasan Penilaian Puskesmas dibagi dalam 3 kategori kawasan, yaitu:

1. Puskesmas berprestasi di wilayah kawasan perkotaan

2. Puskesmas berprestasi di wilayah kawasan perdesaan

3. Puskesmas berprestasi di wilayah kawasan terpencil

terpencil/sangat

Dasar penetapan kategori penilaian adalah perbedaan kondisi geografi dan iklim yang akan mempengaruhi input, proses dan output kegiatan di Puskesmas sesuai Permenkes Nomor 75 tahun 2014.

B. Variabel Penilaian meliputi:

1. Administrasi dan Manajemen, terdiri dari:
a. Analisis kebutuhan masyarakat dan perencanaan Puskesmas
b. Kepemimpinan dan Manajemen Puskesmas
c. Peningkatan Mutu Puskesmas

2. Penyelenggaraan Upaya Kesehatan Masyarakat, terdiri dari:
a. Upaya Puskesmas yang berorientasi sasaran (menurut pendekatan life cycle)
b. Kepemimpinan dan Manajemen Upaya Puskesmas


c. Berorientasi sasaran kinerja dan MDG's

3. Penyelenggaraan

Upaya

Kesehatan Perseorangan, terdiri dari:
a. Layanan klinis yang berorientasi pasien
b. Manajemen penunjang layanan klinis
c. Peningkatan mutu klinis dan keselamatan pasien
d. Cek ulang Administrasi dan Manajemen, UKM dan UKP
e. Indikator Kinerja Puskesmas

f. Upaya Kesehatan Masyarakat Pengembangan, Upaya Inovasi dan Penghargaan

Selanjutnya Peraturan Menteri Kesehatan RI No.741/Menkes/Per/VII/2008 tentang Standar Pelayanan Minimal Bidang Kesehatan Kabupaten Kota, yang mencakup 4 jenis pelayanan, terdiri dari: Pelayanan kesehatan dasar, pelayanan kesehatan rujukan, penyelidikan epidemiologi dan penanggulangan KLB, promosi kesehatan dan pemberdayaan masyarakat.

Tabel 1. Capaian Standar Pelayanan Minimal Puskesmas Metro Periode 2016-2018

\begin{tabular}{|c|c|c|c|c|c|c|c|}
\hline \multirow{2}{*}{ No. } & \multirow{2}{*}{$\begin{array}{c}\text { Nama } \\
\text { Puskesmas }\end{array}$} & \multicolumn{2}{|c|}{ Standar Pelayanan Minimal } & \multicolumn{3}{|c|}{ Capaian } & \multirow[t]{2}{*}{ Ket } \\
\hline & & Jenis Pelayanan & Target & 2016 & 2017 & 2018 & \\
\hline \multirow[t]{4}{*}{1.} & \multirow{4}{*}{$\begin{array}{l}\text { Puskesmas } \\
\text { Sumber Sari } \\
\text { Bantul }\end{array}$} & $\begin{array}{l}\text { Pelayanan kesehatan } \\
\text { dasar }\end{array}$ & $95 \%$ & $80 \%$ & $80 \%$ & $85 \%$ & Baik \\
\hline & & $\begin{array}{l}\text { Pelayanan kesehatan } \\
\text { rujukan }\end{array}$ & $95 \%$ & $85 \%$ & $90 \%$ & $85 \%$ & Baik \\
\hline & & $\begin{array}{l}\text { Penyelidikan } \\
\text { epidemiologi dan } \\
\text { penanggulangan KLB }\end{array}$ & $90 \%$ & $65 \%$ & $65 \%$ & $67 \%$ & Kurang baik \\
\hline & & $\begin{array}{l}\text { Promosi kesehatan dan } \\
\text { pemberdayaan } \\
\text { masyarakat }\end{array}$ & $100 \%$ & $80 \%$ & $90 \%$ & $90 \%$ & Baik \\
\hline \multirow[t]{4}{*}{2.} & \multirow[t]{4}{*}{$\begin{array}{l}\text { Puskesmas } \\
\text { Ganjar Agung }\end{array}$} & $\begin{array}{l}\text { Pelayanan kesehatan } \\
\text { dasar }\end{array}$ & $95 \%$ & $90 \%$ & $90 \%$ & $90 \%$ & Baik \\
\hline & & $\begin{array}{l}\text { Pelayanan kesehatan } \\
\text { rujukan }\end{array}$ & $95 \%$ & $71 \%$ & $70 \%$ & $70 \%$ & Kurang baik \\
\hline & & $\begin{array}{l}\text { Penyelidikan } \\
\text { epidemiologi dan } \\
\text { penanggulangan KLB }\end{array}$ & $90 \%$ & $65 \%$ & $67 \%$ & $67 \%$ & Kurang baik \\
\hline & & $\begin{array}{l}\text { Promosi kesehatan dan } \\
\text { pemberdayaan } \\
\text { masyarakat }\end{array}$ & $100 \%$ & $90 \%$ & $90 \%$ & $95 \%$ & Baik \\
\hline \multirow[t]{4}{*}{3.} & \multirow[t]{4}{*}{$\begin{array}{l}\text { Puskesmas } \\
\text { Mulyojati }\end{array}$} & $\begin{array}{l}\text { Pelayanan kesehatan } \\
\text { dasar }\end{array}$ & $95 \%$ & $80 \%$ & $85 \%$ & $90 \%$ & Baik \\
\hline & & $\begin{array}{l}\text { Pelayanan kesehatan } \\
\text { rujukan }\end{array}$ & $95 \%$ & $70 \%$ & $70 \%$ & $73 \%$ & Kurang baik \\
\hline & & $\begin{array}{l}\text { Penyelidikan } \\
\text { epidemiologi dan } \\
\text { penanggulangan KLB }\end{array}$ & $90 \%$ & $65 \%$ & $70 \%$ & $73 \%$ & Kurang baik \\
\hline & & $\begin{array}{l}\text { Promosi kesehatan dan } \\
\text { pemberdayaan } \\
\text { masyarakat }\end{array}$ & $100 \%$ & $80 \%$ & $85 \%$ & $90 \%$ & Baik \\
\hline \multirow[t]{2}{*}{4.} & \multirow[t]{2}{*}{$\begin{array}{l}\text { Puskesmas } \\
\text { Iringmulyo }\end{array}$} & $\begin{array}{ll}\text { Pelayanan kesehatan } \\
\text { dasar }\end{array}$ & $95 \%$ & $90 \%$ & $90 \%$ & $90 \%$ & Baik \\
\hline & & Pelayanan kesehatan & $95 \%$ & $68 \%$ & $70 \%$ & $73 \%$ & Kurang baik \\
\hline
\end{tabular}


DERIVATIF: Jurnal Manajemen

Vol. 14 No. 1 April 2020

(ISSN Cetak 1978-6573) (ISSN Online 2477-300X)

\begin{tabular}{|c|c|c|c|c|c|c|c|}
\hline \multirow{5}{*}{ No. } & \multirow{5}{*}{$\begin{array}{c}\text { Nama } \\
\text { Puskesmas }\end{array}$} & \multicolumn{2}{|c|}{ Standar Pelayanan Minimal } & \multicolumn{3}{|c|}{ Capaian } & \multirow[t]{2}{*}{ Ket } \\
\hline & & Jenis Pelayanan & Target & 2016 & 2017 & 2018 & \\
\hline & & rujukan & & & & & \\
\hline & & $\begin{array}{l}\text { Penyelidikan } \\
\text { epidemiologi dan } \\
\text { penanggulangan KLB }\end{array}$ & $90 \%$ & $75 \%$ & $75 \%$ & $80 \%$ & Kurang baik \\
\hline & & $\begin{array}{l}\text { Promosi kesehatan dan } \\
\text { pemberdayaan } \\
\text { masyarakat }\end{array}$ & $100 \%$ & $85 \%$ & $90 \%$ & $95 \%$ & Baik \\
\hline \multirow[t]{4}{*}{5.} & \multirow[t]{4}{*}{$\begin{array}{l}\text { Puskesmas } \\
\text { Yosodadi }\end{array}$} & $\begin{array}{l}\text { Pelayanan kesehatan } \\
\text { dasar }\end{array}$ & $95 \%$ & $65 \%$ & $70 \%$ & $70 \%$ & Kurang baik \\
\hline & & $\begin{array}{l}\text { Pelayanan kesehatan } \\
\text { rujukan }\end{array}$ & $95 \%$ & $80 \%$ & $80 \%$ & $85 \%$ & Baik \\
\hline & & $\begin{array}{l}\text { Penyelidikan } \\
\text { epidemiologi dan } \\
\text { penanggulangan KLB }\end{array}$ & $90 \%$ & $70 \%$ & $70 \%$ & $70 \%$ & Kurang baik \\
\hline & & $\begin{array}{l}\text { Promosi kesehatan dan } \\
\text { pemberdayaan } \\
\text { masyarakat }\end{array}$ & $100 \%$ & $70 \%$ & $70 \%$ & $70 \%$ & Kurang baik \\
\hline \multirow[t]{4}{*}{6.} & \multirow[t]{4}{*}{$\begin{array}{l}\text { Puskesmas } \\
\text { Tejo Agung }\end{array}$} & $\begin{array}{l}\text { Pelayanan kesehatan } \\
\text { dasar }\end{array}$ & $95 \%$ & $68 \%$ & $72 \%$ & $72 \%$ & Kurang baik \\
\hline & & $\begin{array}{l}\text { Pelayanan kesehatan } \\
\text { rujukan }\end{array}$ & $95 \%$ & $80 \%$ & $85 \%$ & $90 \%$ & Baik \\
\hline & & $\begin{array}{l}\text { Penyelidikan } \\
\text { epidemiologi dan } \\
\text { penanggulangan KLB }\end{array}$ & $90 \%$ & $80 \%$ & $80 \%$ & $80 \%$ & Baik \\
\hline & & $\begin{array}{l}\text { Promosi kesehatan dan } \\
\text { pemberdayaan } \\
\text { masyarakat }\end{array}$ & $100 \%$ & $70 \%$ & $73 \%$ & $75 \%$ & Kurang baik \\
\hline \multirow[t]{4}{*}{7.} & \multirow[t]{4}{*}{$\begin{array}{l}\text { Puskesmas } \\
\text { Yosomulyo }\end{array}$} & $\begin{array}{ll}\begin{array}{l}\text { Pelayanan kesehatan } \\
\text { dasar }\end{array} & \\
\end{array}$ & $95 \%$ & $75 \%$ & $75 \%$ & $77 \%$ & Kurang baik \\
\hline & & $\begin{array}{l}\text { Pelayanan kesehatan } \\
\text { rujukan }\end{array}$ & $95 \%$ & $80 \%$ & $80 \%$ & $80 \%$ & Baik \\
\hline & & $\begin{array}{l}\text { Penyelidikan } \\
\text { epidemiologi dan } \\
\text { penanggulangan KLB }\end{array}$ & $90 \%$ & $67 \%$ & $71 \%$ & $75 \%$ & Kurang baik \\
\hline & & $\begin{array}{l}\text { Promosi kesehatan dan } \\
\text { pemberdayaan } \\
\text { masyarakat }\end{array}$ & $100 \%$ & $70 \%$ & $75 \%$ & $75 \%$ & Kurang baik \\
\hline \multirow[t]{4}{*}{8.} & \multirow[t]{4}{*}{$\begin{array}{l}\text { Puskesmas } \\
\text { Metro }\end{array}$} & $\begin{array}{l}\text { Pelayanan kesehatan } \\
\text { dasar }\end{array}$ & $95 \%$ & $80 \%$ & $80 \%$ & $80 \%$ & Baik \\
\hline & & $\begin{array}{l}\text { Pelayanan kesehatan } \\
\text { rujukan }\end{array}$ & $95 \%$ & $80 \%$ & $85 \%$ & $90 \%$ & Baik \\
\hline & & $\begin{array}{l}\text { Penyelidikan } \\
\text { epidemiologi dan } \\
\text { penanggulangan KLB }\end{array}$ & $90 \%$ & $65 \%$ & $70 \%$ & $70 \%$ & Kurang baik \\
\hline & & $\begin{array}{l}\text { Promosi kesehatan dan } \\
\text { pemberdayaan } \\
\text { masyarakat }\end{array}$ & $100 \%$ & $75 \%$ & $75 \%$ & $75 \%$ & Kurang baik \\
\hline \multirow[t]{3}{*}{9.} & \multirow[t]{3}{*}{$\begin{array}{l}\text { Puskesmas } \\
\text { Banjar Sari }\end{array}$} & $\begin{array}{ll}\text { Pelayanan kesehatan } \\
\text { dasar }\end{array}$ & $95 \%$ & $90 \%$ & $90 \%$ & $90 \%$ & Baik \\
\hline & & $\begin{array}{l}\text { Pelayanan kesehatan } \\
\text { rujukan }\end{array}$ & $95 \%$ & $70 \%$ & $70 \%$ & $73 \%$ & Kurang baik \\
\hline & & $\begin{array}{l}\text { Penyelidikan } \\
\text { epidemiologi dan }\end{array}$ & $90 \%$ & $70 \%$ & $70 \%$ & $70 \%$ & Kurang baik \\
\hline
\end{tabular}


DERIVATIF: Jurnal Manajemen

Vol. 14 No. 1 April 2020

(ISSN Cetak 1978-6573) (ISSN Online 2477-300X)

\begin{tabular}{|c|c|c|c|c|c|c|c|}
\hline \multirow{4}{*}{ No. } & \multirow{4}{*}{$\begin{array}{c}\text { Nama } \\
\text { Puskesmas }\end{array}$} & \multicolumn{2}{|c|}{ Standar Pelayanan Minimal } & \multicolumn{3}{|c|}{ Capaian } & \multirow[t]{2}{*}{ Ket } \\
\hline & & Jenis Pelayanan & Target & 2016 & 2017 & 2018 & \\
\hline & & penanggulangan KLB & & & & & \\
\hline & & $\begin{array}{l}\text { Promosi kesehatan dan } \\
\text { pemberdayaan } \\
\text { masyarakat }\end{array}$ & $100 \%$ & $75 \%$ & $75 \%$ & $77 \%$ & Kurang baik \\
\hline \multirow[t]{4}{*}{10.} & \multirow[t]{4}{*}{$\begin{array}{l}\text { Puskesmas } \\
\text { Purwo Sari }\end{array}$} & $\begin{array}{l}\text { Pelayanan kesehatan } \\
\text { dasar }\end{array}$ & $95 \%$ & $85 \%$ & $90 \%$ & $90 \%$ & Baik \\
\hline & & $\begin{array}{l}\text { Pelayanan kesehatan } \\
\text { rujukan }\end{array}$ & $95 \%$ & $65 \%$ & $65 \%$ & $77 \%$ & Kurang baik \\
\hline & & $\begin{array}{l}\text { Penyelidikan } \\
\text { epidemiologi dan } \\
\text { penanggulangan KLB }\end{array}$ & $90 \%$ & $70 \%$ & $75 \%$ & $75 \%$ & Kurang baik \\
\hline & & $\begin{array}{l}\text { Promosi kesehatan dan } \\
\text { pemberdayaan } \\
\text { masyarakat }\end{array}$ & $100 \%$ & $80 \%$ & $87 \%$ & $90 \%$ & Baik \\
\hline \multirow[t]{4}{*}{11.} & \multirow[t]{4}{*}{$\begin{array}{l}\text { Puskesmas } \\
\text { Karang Rejo }\end{array}$} & $\begin{array}{l}\text { Pelayanan kesehatan } \\
\text { dasar }\end{array}$ & $95 \%$ & $80 \%$ & $85 \%$ & $90 \%$ & Baik \\
\hline & & $\begin{array}{l}\text { Pelayanan kesehatan } \\
\text { rujukan }\end{array}$ & $95 \%$ & $65 \%$ & $75 \%$ & $65 \%$ & Kurang baik \\
\hline & & $\begin{array}{l}\text { Penyelidikan } \\
\text { epidemiologi dan } \\
\text { penanggulangan KLB }\end{array}$ & $90 \%$ & $65 \%$ & $65 \%$ & $67 \%$ & Kurang baik \\
\hline & & $\begin{array}{l}\text { Promosi kesehatan dan } \\
\text { pemberdayaan } \\
\text { masyarakat }\end{array}$ & $100 \%$ & $70 \%$ & $70 \%$ & $75 \%$ & Kurang baik \\
\hline
\end{tabular}

Sumber: Dinas Kesehatan Kota Metro (2019)

Berdasarkan tabel di atas dapat disimpulkan bahwa penerapan sistem reputasi layanan publik pada Puskesmas Metro belum berjalan secara maksimal dengan yang ditargetkan, terlihat dari beberapa indikator standar pencapaian pelayanan minimal yang belum berjalan secara baik (kurang baik). Adanya hal tersebut kemungkinan disebabkan oleh kinerja tenaga medis dan pelayanan kesehatan yang diberikan oleh tenaga medis belum optimal diberikan kepada masyarakat.

Penerapan sistem reputasi publik layanan merupakan terobosan baru pemerintah Metro dalam pembenahan pelayanan kepada masyarakat dengan cara masyarakat itu sendiri yang memberikan penilaian melalui smartphone. Dengan kecanggihan teknologi tersebut kiranya masyarakat dapat antusias berpartisipasi untuk memperbaiki sistem pelayanan yang ada didalamnya dan membentuk reputasi (image) yang baik sehingga masyarakat yang selama ini enggan untuk memeriksakan kesehatannya dapat segera datang ke puskesmas.

Penerapan sistem reputasi layanan publik sebenarnya belum berjalan bergitu lama sehingga tidak banyak masyarakat yang mulai menggunakannya. Meskipun telah disosialisasikan secara berkesinambung kepada masyarakat, namun hal tersebut belum efektif kepada masyarakat yang tidak memiliki smartphone dan telah berusia lanjut usia. Selain itu, hasil penelitian yang dikemukakan oleh Mahendra \& Pribadi (2016: 60) menyatakan bahwa pengaduan layanan (komplain) melalui kotak saran dinilai belum efektif, dikarenakan tidak memungkinkan petugas untuk membaca secara keseluruhan komplain masyarakat satu persatu dan tidak disediakannya alat tulis maupun kertas untuk menulis saran, menjadikan masyarakat memilih melakukan komplain secara langsung 


\section{DERIVATIF: Jurnal Manajemen}

\section{Vol. 14 No. 1 April 2020 \\ (ISSN Cetak 1978-6573) (ISSN Online 2477-300X)}

kepada tenaga medis yang bertugas pada saat itu.

Dalam rangka penerapan reputasi layanan publik dengan menyediakan sarana, prasarana, fasilitas berupa desk layanan informasi, fasilitas pendukung seperti layanan akses internet gratis, petugas pelaksana layanan informasi, instrumen transaksi, produk pelayanan, serta menetapkan waktu layanan informasi. Hal ini sesuai dengan Peraturan Menteri Komunikasi dan Informatika Nomor 1 Tahun 2016 Tentang Organisasi dan Tata Kerja Kementerian Komunikasi dan Informatika.

Pemerintah Kota Metro, mentargetkan seluruh Puskesmas bisa menyandang status ter-Akreditasi. Hal tersebut disampaikan Wali Metro Achmad Pairin, saat menghadiri acara Survei Reakreditasi Puskesmas Kota
Metro. Menurutnya, Puskesmas di Metro yang sudah terakreditasi berjumlah 11 Puskesmas, dan 1 Puskesmas baru akan maju akreditasi pada bulan Desember mendatang. Akreditasi Puskesmas ini bertujuan untuk meningkatkan mutu pelayanan dan kesehatan pasien, meningkatkan perlindungan bagi SDM Kesehatan, serta meningkatkan kinerja Puskesmas. Penerapan reputasi layanan publik akan dinilai sukses apabila mutu pelayanan dan kesehatan pasien dapat berjalan seperti apa yang diharapkan oleh masyarakat sebagai penikmat layanan publik

(https://web.lintaslampung.com/achmadpairin-targetkan-semua-puskesmas-dikota-metro-terakreditasi).

Berikut ini adalah hasil uji coba yang dilakukan oleh KEMINFO terhadap beberapa masyarakat dalam penerapan sistem reputasi layanan publik.

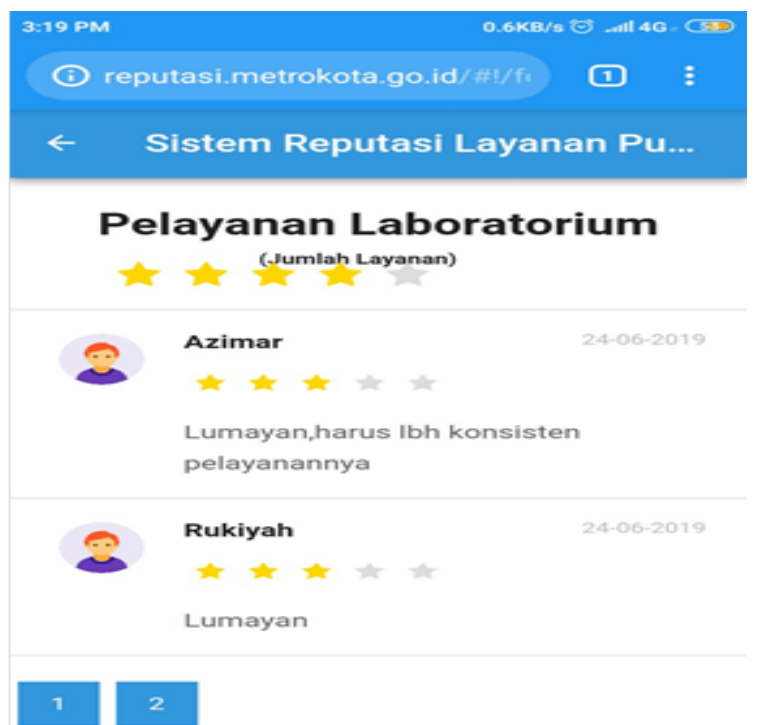

Gambar 1. Hasil Uji Coba Sistem Reputasi Layanan Publik

Berdasarkan gambar di atas menunjukkan bahwa sosialisasi sistem reputasi layanan publik sudah dapat berjalan dengan baik. Hasil penilaian masyarakat menunjukkan bahwa masih terdapat keluhan masyarakat terkait dengan kinerja tenaga medis dan pelayanan kesehatan oleh Puskesmas Metro.

\section{A. Sistem Reputasi Layanan Publik}

Reputasi yang baik akan mudah di ingat oleh masyarakat, namun reputasi yang tidak baik juga selalu terbesit pada benak 
masyarakat. Pembentukan reputasi perlu dilakukan sejak dini sehingga lebih mudah untuk menghadapi problematika yang terkait dengan hal tersebut (Yanuar, 2017: 5).

Dalam

menciptakan

kesuksesan pada suatu pelayanan publik adalah dengan cara memperbaharui personal pegawai sehingga dapat mencapai kinerja jangka panjang (Harlim, 2008: 44). Pembaharuan pada diri pegawai diharapkan dapat memunculkan pelayanan yang terbaik dan mudah diterima oleh masyarakat. Pelayanan publik didefinisikan sebagai bentuk interaksi pemerintah dengan masyarakat (Dwiyanto, 2018: 67).

\section{B. Pelayanan Kesehatan}

Kegiatan yang terbentuk dalam meningkatkan kesehatan yang diperankan oleh pemerintah maupun masyarakat selaku yang berhak mendapatkan kesehatan dapat dikatakan sebagai upaya kesehatan (Notoatmodjo, 2005: 66). Selanjutnya, berdasarkan UndangUndang Republik Indonesia No. 36 Tahun 2009 pasal 1 ayat 11 pengertian pelayanan kesehatan adalah "setiap kegiatan dan/atau serangkaian kegiatan yang dilakukan secara terpadu, terintegrasi dan berkesinambungan untuk memelihara dan meningkatkan derajat kesehatan, pengobatan penyakit, dan pemulihan kesehatan oleh pemerintah dan/atau masyarakat".

$$
\text { Pelayanan digambarkan }
$$

sebagai tindakan yang tidak berwujud yang diberikan oleh pihak lain sehingga tidak mengakibatkan adanya pelabelan dalam kepemilikan sesuatu (Sirait, 2016: 345). Setiap masyarakat tentunya ingin mendapatkan pelayanan kesehatan yang layak, namun terkendala dengan keterbatasan penyedia jasa layanan membuat masyarakat kecewa. Penyampaian secara baik dapat membentuk ekspektasi dibenak para masyarakat yang hendak berkunjung ke tempat penyedia jasa layanan kesehatan, (Kumayza, 2013: 617). Hal ini dapat diartikan bahwa cara penyampaian informasi yang tepat dapat membuat masyarakat merasa puas.

\section{Kinerja Tenaga Medis}

Kinerja atau prestasi kerja adalah hasil kerja secara kualitas dan kuantitas yang dicapai oleh seorang tenaga medis dalam melaksanakan tugasnya sesuai dengan tanggung jawab yang diberikan kepadanya. Kinerja dapat dimaknai juga sebagai hasil kerja yang di tunjukkan oleh seorang tenaga medis ditinjau dari segi kualitas maupun kuantitasnya, (Tejo \& Machasin, 2015: 440).

Kinerja tenaga medis merupakan hasil perbandingan dari hasil pelaksanaan tugas seseorang dalam periode tertentu dan memiliki kegunaan untuk mengukur hasil prestasi tenaga medis, (Farid dkk, 2016: 77). Maksudnya kinerja tenaga medis sebagai bentuk ukuran digunakan untuk membandingkan hasil pelaksanaan tanggungjawab tenaga medis dalam bekerja untuk mengukur sampai sejauh mana kinerja organisasi berlangsung.

\section{METODE PENELITIAN}

Penelitian ini dilakukan pada Puskesmas Metro pada tanggal 28 November 2019. Jenis penelitian dengan menggunakan pendekatan kuantitatif dan teknik pengumpulan data menggunakan observasi dan kuesioner. Populasi dalam penelitian ini berjumlah 90 orang dan di analisis menggunakan regresi linear berganda dengan bantuan SPSS versi 21. 
DERIVATIF: Jurnal Manajemen

Vol. 14 No. 1 April 2020

(ISSN Cetak 1978-6573) (ISSN Online 2477-300X)

\section{HASIL DAN PEMBAHASAN}

\section{A. Hasil}

1. Uji Normalitas

Tabel 2. Hasil Uji Normalitas

Tests of Normality

\begin{tabular}{|l|r|r|r|r|r|r|}
\hline & \multicolumn{3}{|c|}{ Kolmogorov-Smirnov $^{\mathrm{a}}$} & \multicolumn{3}{c|}{ Shapiro-Wilk } \\
\cline { 2 - 7 } & Statistic & \multicolumn{1}{c|}{$\mathrm{df}$} & \multicolumn{1}{c|}{ Sig. } & Statistic & \multicolumn{1}{c|}{$\mathrm{df}$} & \multicolumn{1}{c|}{ Sig. } \\
\hline SRLP & .131 & 90 & .001 & .977 & 90 & .103 \\
PK & .079 & 90 & $.200^{*}$ & .983 & 90 & .276 \\
KTM & .093 & 90 & .052 & .980 & 90 & .177 \\
\hline
\end{tabular}

$*$. This is a lower bound of the true significance.

a. Lilliefors Significance Correction

Berdasarkan tabel 2 menunjukkan bahwa variabel Sistem Reputasi Layanan Publik memiliki nilai sig. $0,103>0,05$, variabel pelayanan kesehatan memiliki nilai sig. $0,276>0,05$, dan variabel kinerja tenaga medis memiliki nilai sig. $0,177>0,05$ sehingga dapat disimpulkan ketiga variabel tersebut berdistribusi normal.

2. Hasil Uji Homogenitas

Tabel 3. Hasil Uji Homogenitas

\begin{tabular}{|l|c|c|c|c|}
\hline \multicolumn{1}{|c|}{ Variabel } & Levene Statistic & df1 & df2 & Sig. \\
\hline Kinerja Tenaga Medis & 1,863 & 18 & 62 & 0,077 \\
\hline Pelayanan Kesehatan & 1,758 & 17 & 59 & 0,057 \\
\hline
\end{tabular}

Dari tabel 3 di atas diketahui bahwa signifikansi yang diperoleh $>\alpha(0,05)$, sehingga dapat disimpulkan bahwa Sistem Reputasi Layanan Publik (Y) atas
Kinerja Tenaga Medis $\left(\mathrm{X}_{1}\right)$ dan Pelayanan Kesehatan $\left(\mathrm{X}_{2}\right)$ berasal dari kelompok yang homogen.

3. Hasil Uji Linieritas

Tabel 4. Hasil Uji Linieritas

\begin{tabular}{|c|l|c|c|c|}
\hline \multirow{2}{*}{ No. } & Variabel & \multicolumn{2}{|c|}{ Deviation from Linearity } & \multirow{2}{*}{ Ket. } \\
\cline { 3 - 4 } & & $\mathrm{F}$ & Sig. & \\
\hline 1 & Kinerja Tenaga Medis $\left(\mathrm{X}_{1}\right)$ & 1,173 & 0,298 & Linier \\
\hline 2 & Pelayanan Kesehatan $\left(\mathrm{X}_{2}\right)$ & 0,855 & 0,671 & Linier \\
\hline
\end{tabular}

Berdasarkan tabel 4 hasil uji linieritas tersebut dapat disimpulkan bahwa data tersebut variabelnya memiliki hubungan yang linier antara Kinerja Tenaga Medis $\left(\mathrm{X}_{1}\right)$ dan Pelayanan b.
Kesehatan $\left(\mathrm{X}_{2}\right)$ terhadap Sistem Reputasi Layanan Publik (Y).

4. Hasil Pengujian Hipotesis

a. Hasil Uji $\mathrm{t}$ 
Tabel 5. Hasil Uji t

Coefficients $^{\mathbf{a}}$

\begin{tabular}{|rl|r|r|r|r|r|}
\hline \multirow{2}{*}{ Model } & \multicolumn{2}{|c|}{$\begin{array}{c}\text { Unstandardized } \\
\text { Coefficients }\end{array}$} & $\begin{array}{c}\text { Standardized } \\
\text { Coefficients }\end{array}$ & \multirow{2}{*}{$\mathrm{t}$} & \multirow{2}{*}{ Sig. } \\
\cline { 2 - 5 } & \multicolumn{1}{|c|}{ B } & Std. Error & \multicolumn{1}{c|}{ Beta } & & \\
\hline \multirow{2}{*}{1} & (Constant) & 59.758 & 9.866 & & 6.057 & .000 \\
& KTM & .330 & .131 & .237 & 2.513 & .014 \\
& PK & .417 & .098 & .402 & 4.248 & .000 \\
\hline
\end{tabular}

a. Dependent Variable: KTM

Berdasarkan model persamaan regresi antara Kinerja Tenaga Medis $\left(\mathrm{X}_{1}\right)$ dan Pelayanan Kesehatan $\left(\mathrm{X}_{2}\right)$ dengan Sistem Reputasi Layanan Publik (Y) diperoleh hasil $\hat{\mathrm{Y}}=$ $59.758+0,237 \mathrm{X}_{1}+$ $0,402 \mathrm{X}_{2}$. Pada tabel 12 menunjukkan bahwa antara Kinerja tenaga medis $\left(\mathrm{X}_{1}\right)$ memiliki nilai $t_{\text {hitung }} 2,513>$ 1,99 dan nilai sig. $0,014<$ 0,05 sehingga dapat disimpulkan bahwa Kinerja
Tenaga Medis memiliki pengaruh positif terhadap Sistem Reputasi Layanan Publik. Selain itu, Pelayanan Kesehatan memiliki nilai $t_{\text {hitung }} 4,248>$ 1,99 dan nilai sig. $0,000<$ 0,05 sehingga dapat disimpulkan bahwa Pelayanan Kesehatan memiliki pengaruh positif terhadap Kinerja Tenaga Medis.

c. Hasil Uji f

Tabel 62. Hasil Uji f

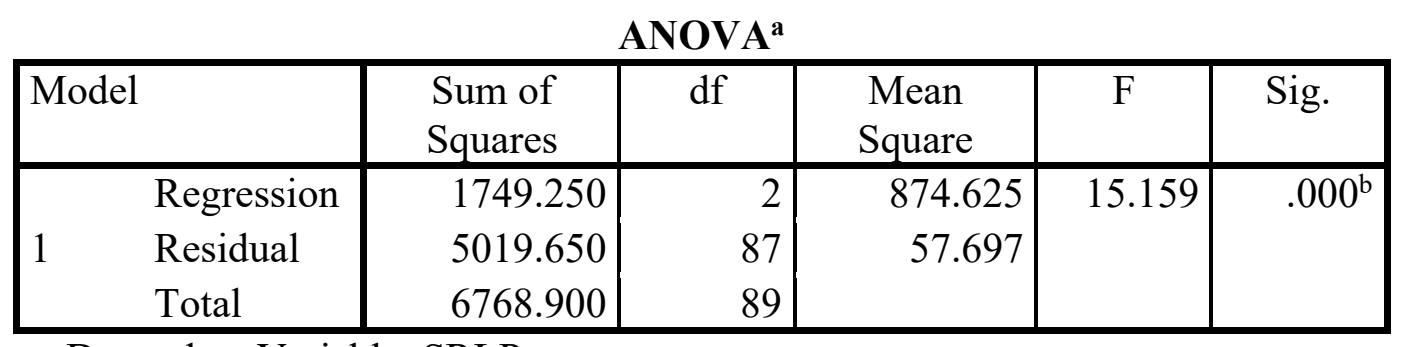

a. Dependent Variable: SRLP

b. Predictors: (Constant), KTM, PK,

Berdasarkan pada tabel 6 menunjukkan bahwa variabel Kinerja Tenaga Medis $\left(\mathrm{X}_{1}\right)$ dan Pelayanan Kesehatan $\left(\mathrm{X}_{2}\right)$ memiliki pengaruh secara simultan terhadap Sistem Reputasi
Layanan Publik (Y). Hal ini disebabkan nilai $F_{\text {hitung }}$ $15,159>\mathrm{F}_{\text {tabel }} 3,10$ dan nilai sig. $0,000<0,05$.

d. Hasil Koefisien Determinasi 


\section{DERIVATIF: Jurnal Manajemen}

\section{Vol. 14 No. 1 April 2020 \\ (ISSN Cetak 1978-6573) (ISSN Online 2477-300X)}

Tabel 7. Hasil Koefisien Determinasi

Model Summary

\begin{tabular}{|l|r|r|r|r|}
\hline $\begin{array}{l}\text { Mode } \\
1\end{array}$ & \multicolumn{1}{|c|}{$\mathrm{R}$} & R Square & $\begin{array}{c}\text { Adjusted R } \\
\text { Square }\end{array}$ & $\begin{array}{c}\text { Std. Error of } \\
\text { the Estimate }\end{array}$ \\
\hline 1 & $.508^{\mathrm{a}}$ & .258 & .241 & 7.596 \\
\hline
\end{tabular}

a. Predictors: (Constant), PK, KTM

Berdasarkan tabel di atas menunjukkan $\mathrm{R}^{2}$ yaitu $0,241 \quad(24,1 \%) \quad$ sehingga dapat disimpulkan bahwa Kinerja Tenaga Medis $\left(\mathrm{X}_{1}\right)$ dan Pelayanan Kesehatan $\left(\mathrm{X}_{2}\right)$ memiliki pengaruh terhadap Sistem Reputasi Layanan Publik (Y) sebesar $24,1 \%$ dan sisanya $75,9 \%$ dipengaruhi oleh variabel lain yang tidak di bahas pada penelitian ini.

\section{B. Pembahasan}

1. Pengaruh Kinerja Tenaga Medis terhadap Sistem Reputasi Layanan Publik

Berdasarkan hasil penelitian menunjukkan bahwa Kinerja Tenaga Medis memiliki pengaruh yang signifikan terhadap Sistem Reputasi Layanan Publik. Pengaruh ini menandakan bawah kinerja yang dimiliki oleh seseorang akan mempengaruhi sistem reputasi layanan publik pada suatu organisasi. Kinerja tenaga medis sendiri memiliki makna sebagai gambaran mengenai tingkat pencapaian pelaksanaan suatu kebijakan dalam mewujudkan sasaran, tujuan, misi dan visi organisasi yang tertuang dalam perencanaan strategis suatu organisasi. Istilah kinerja sering digunakan untuk menyebut prestasi atau tingkat keberhasilan individu maupun kelompok. Kinerja bisa diketahui hanya jika individu atau kelompok tersebut mempunyai kriteria keberhasilan yang telah ditetapkan sebelumnya.

Sistem reputasi layanan publik akan menjadi baik apabila kinerja tenaga medis dapat menjalankan tugas yang dibebankan kepadanya secara baik pula, karena sistem reputasi layanan publik dapat pula dijadikan sebagai tolak ukur keberhasilan akan kinerja seorang tenaga medis.

2. Pengaruh Pelayanan Kesehatan terhadap Sistem Reputasi Layanan Publik

Berdasarkan hasil penelitian menunjukkan bahwa Pelayanan Kesehatan memiliki pengaruh yang signifikan terhadap Sistem Reputasi Layanan Publik. Pengaruh ini dapat dimaknai bahwa pelayanan kesehatan yang diberikan oleh seseorang pada Puskesmas akan berdampak pada sistem reputasi layanan publik.

Pelayanan kesehatan yang baik tidak hanya di ukur dari sarana maupun prasarana, melainkan bagaimana cara berkomunikasi dan beretika para pegawai terhadap para masyarakat. Apabila pelayanan kesehatan diaplikasikan dengan sepenuh hati secara otomatis akan meningkatkan sistem reputasi layanan publik. 
Tenaga medis yang berpotensi harus di jaga dan di pertahankan dengan baik serta di manfaatkan dengan baik pula, karena pada dasarnya organisasi tidak hanya ingin mencapai tujuan pada satu waktu, melainkan untuk jangka panjang dan salah satunya adalah pelayanan kesehatan yang baik. Baik buruknya pelayanan kesehatan akan mempengaruhi sistem reputasi layanan publik yang diberikan kepada masyarakat/pasien.

3. Pengaruh Kinerja Tenaga Medis dan Pelayanan Kesehatan terhadap Sistem Reputasi Layanan Publik

Berdasarkan hasil penelitian menunjukkan bahwa Kinerja tenaga medis dan Pelayanan kesehatan memiliki pengaruh secara bersama-sama terhadap Sistem reputasi layanan publik. Ditemukannya pengaruh tersebut menggambarkan apabila seseorang tenaga medis yang memiliki kemampuan baik secara kualitas, kuantitas dalam menjalankan pekerjaannya sebagai pelayan masyarakat/pasien dapat meningkatkan sistem reputasi layanan publik secara maksmimal dikarenakan kompetensi yang dimilikinya, selain itu tenaga medis yang berkompeten tersebut secara otomatis dapat memberikan pelayanan kesehatan sesuai standar operasional puskesmas dan peraturan perundang-undangan, karena tidak semua tenaga medis itu mampu memahami seluruh standar operasinal puskesmas kecuali tenaga medis yang berkompeten, dengan begitu akan terciptalah suatu sistem reputasi layanan publik yang baik.

Jadi, kinerja tenaga medis dan pelayanan kesehatan apabila dipelihara dan dilakukan dengan baik maka akan berdampak pada meningkatnya sistem reputasi layanan publik.

\section{KESIMPULAN}

A. Berdasarkan perhitungan analisis dapat disimpulkan bahwa terdapat pengaruh Kinerja tenaga medis terhadap Sistem reputasi layanan publik pada Puskesmas Metro. Hal ini disebabkan karena Kinerja tenaga medis telah baik sehingga mampu meningkatkan Sistem reputasi layanan publik.

B. Berdasarkan perhitungan analisis dapat disimpulkan bahwa terdapat pengaruh Pelayanan Kesehatan terhadap Sistem reputasi layanan publik pada Puskesmas Metro. Hal ini disebabkan karena Pelayanan kesehatan telah menjalankan tugasnya dengan baik sehingga mampu meningkatkan Sistem reputasi layanan publik.

C. Berdasarkan perhitungan analisis dapat disimpulkan bahwa terdapat pengaruh Kinerja tenaga medis dan Pelayanan kesehatan secara bersamasama terhadap Sistem reputasi layanan publik pada Puskesmas Metro. Hal ini disebabkan karena adanya kombinasi yang maksimal antara Kinerja tenaga medis dan Pelayanan kesehatan sehingga mampu meningkatkan Sistem reputasi layanan publik.

\section{DAFTAR PUSTAKA}

Dwiyanto, A. (2018). Manajemen Pelayanan Publik: Peduli Inklusif dan Kolaborasi. Yogyakarta: UGM PRESS. 
Farid, H.T., Hamid, D., \& Nurtjahjono, G.E. (2016). Pengaruh Motivasi Kerja terhadap Kedisiplinan dan Kinerja Pegawai PT. PLN Distribusi Jawa Timur Area Malang. Jurnal Administrasi Bisnis, 32(1), 75-81.

Harlim, Y. (2008). Membangun Reputasi Perusahaan sebagai Langkah Peningkatan Loyalitas Pelanggan. Jurnal Sains Pemasaran Indonesia, 7(1), 39-63.

Informatika, D.K. (2017). Rencana strategis Dinas Komunikasi dan Informatika Pemerintah Metro tahun 2016-2021.

Irmawati, S., Lukman, H., \& Nurhannis. (2017). Kualitas Pelayanan Kesehatan di Puskesmas Sangurara Kecamatan Tatanga Kota Palu. Katalogis, 5(1), 188-197.

Kumayza, T.N. (2013). Analisis Kualitas Pelayanan Pada Kantor Kecamatan Tenggarong Kabupaten Kutai Kartanegara. eJournal Administrative Reform, 1, 614-628.

Notoatmodjo, S. (2005). Promosi Kesehatan Teori dan Aplikasinya. Jakarta: Rineka Cipta.

Saputra, M., \& Harahap, T.K. (2016). Analisis Kinerja Tenaga Medis Puskesmas Kecamatan Kampar Utara Kabupaten Kampar. Jurnal Online Mahasiswa Fakultas Ilmu Sosial dan Ilmu Politik Universitas Riau, 3(2), 1-15.

Sirait, J.N. (2016). Pengaruh Kualitas Pelayanan Terhadap Kepuasan Pelanggan Pada Waterpark Perum Bumi Sempaja di Kota Samarinda. eJournal Administrasi Bisnis, 4, 342355.

Tejo, G.A., \& Machasin. (2015). Pengaruh Kompetensi dan Budaya Organisasi Terhadap Motivasi Kerja Serta Dampaknya Terhadap Kinerja
Personil Bidang Humas Polda Riau. Jurnal Tepak Manajemen Bisnis, 7, 437-454.

Trimanah. (2012). Reputasi Dalam Rangka Kerja Public Relations. Jurnal Ilmu Komunikasi, 3(1), 92-102.

Yanuar, D. (2017). Kekuatan Integrated Communication untuk Membangun Reputasi dalam Menghadapi Krisis. Jurnal Komunikasi Global, 6(1), 114.

Undang-Undang No. 25 Tahun 2009 tentang Pelayanan Publik.

Undang-Undang Republik Indonesia No. 36 Tahun 2009 pasal 1 ayat 11 pengertian pelayanan kesehatan.

Peraturan Menteri Kesehatan Republik Indonesia No. 24 Tahun 2015 tentang Penilaian Fasilitas Kesehatan Tingkat Pertama Berprestasi.

Peraturan Menteri Kesehatan RI No.741/Menkes/Per/VII/2008 tentang Standar Pelayanan Minimal Bidang Kesehatan Kabupaten Kota.

Peraturan Menteri Kesehatan Republik Indonesia Nomor 43 Tahun 2016 tentang Standar Pelayanan Minimal Bidang Kesehatan.

Peraturan Menteri Komunikasi dan Informatika Nomor 1 Tahun 2016 tentang Organisasi dan Tata Kerja Kementerian Komunikasi dan Informatika.

(https://web.lintaslampung.com/achmadpairin-targetkan-semua-puskesmasdi-kota-metro-terakreditasi, diakses tanggal 4 Oktober 2019). 